\title{
14. GENETIC EVIDENCE FOR ENDOLITHIC MICROBIAL LIFE COLONIZING BASALTIC GLASS/SEAWATER INTERFACES ${ }^{1}$
}

\author{
Stephen J. Giovannoni, ${ }^{2}$ Martin R. Fisk, ${ }^{3}$ Thomas D. Mullins, ${ }^{2}$ and Harald Furnes ${ }^{4}$
}

\begin{abstract}
The majority of the Earth's shallow crust is composed of basalt that erupted on the seafloor and was subsequently altered by chemical exchange with seawater. One aspect of this alteration is the replacement of glass by secondary minerals, including clays. Petrographic thin sections from ODP Holes 504B and 896A revealed characteristic patterns of pitting (channels) at the interface of fresh basalt glass and secondary clay. Fluorescent dyes that bind specifically to nucleic acids (Hoechst 33342 , PO-PRO-3, and Syto 1) were used to examine thin sections for evidence of cellular life. Independent experiments with the three dyes indicated the presence of particulate nucleic acids at the interface of altered and unaltered glass, particularly at the distal tips of channels. Organic material was extracted from crushed basalts from Holes 504B and 896A and examined for the presence of microbial DNA by a polymerase chain reaction (PCR) assay. This technique detects specific ribosomal RNA genes that are present in all cellular life-forms. The PCR assays demonstrated the presence of prokaryotic genomic DNA in the rock extracts. Among the geochemical reactions that could provide energy for biological processes are the oxidation of iron, manganese, and sulfur. Electron microprobe analyses of areas of glass that appear to be affected by microbial action have low iron relative to the fresh glass. Also, elements that are consistent with the presence of cellular life, phosphate and potassium, were elevated in the channels ( $\mathrm{P}$ is $0.02 \mathrm{wt} \%$ in glass and up to $1.4 \mathrm{wt} \%$ in channels and $\mathrm{K}$ is $0.01 \mathrm{wt} \%$ in glass and up to $2.0 \mathrm{wt} \%$ in channels). These data raise the possibility that chemical transformations of basalt on the seafloor are mediated by microorganisms.
\end{abstract}

\section{INTRODUCTION}

Substantial evidence supports the view that microorganisms can effect widespread geochemical changes in the atmosphere, hydrosphere, and sediments. In the lithosphere, in contrast, the significance of the influence of microbial life on chemical change is unknown. Thus, it is of considerable interest that microbial communities associated with basalt have been reported (Thorseth et al., 1992). The alteration of basalts to palagonite has been viewed as a physical/ chemical process (Staudigel and Hart, 1983; Crovisier et al., 1987; Thorseth et al., 1991). Evidence that microorganisms participate in this process could precipitate a fundamental shift in scientific perceptions of this problem.

The surface area of pillow basalts in contact with seawater is vast. Water circulation through the oceanic crust results in chemical exchange that modifies seawater chemistry and leaves enormous accumulations of basalt alteration products. The presence of microorganisms at the interface between fresh basaltic glass and seawater raises the possibility that microbial communities may influence chemical exchange in this global arena. Of particular interest are the possibilities that microbial life might control both rates of alteration processes and the composition of products. From a biological standpoint, the temperature range, pressure range, substrates, and evolutionary origins of these putative microbial communities are of keen interest.

Previous studies have implicated microorganisms in various glass transformations (Duff et al., 1963; Webley et al., 1963; Silverman,

'Alt, J.C., Kinoshita, H., Stokking, L.B., and Michael, P.J. (Eds.), 1996. Proc. ODP, Sci. Results, 148: College Station, TX (Ocean Drilling Program).

2Department of Microbiology. Oregon State University, Corvallis, OR 97331 U.S.A. Giovannoni:giovanns@bcc.orst.edu; Mullins: mullinst@fsl.orst.edu

College of Oceanic and Atmospheric Sciences, Oregon State University, Corvallis, OR 97331 U.S.A. mfisk@oce.orst.edu

${ }^{4}$ Geological Institute, University of Bergen, Allegt. 41, 5007 Bergen, Norway. Harald.Furnes@geol.uib.no
1979; Krumbien, 1983; Thorseth et al., 1992; Palmer and Hirsch, 1993; Furnes et al., this volume). However, it has not been established whether the mineral transformations provide the energy for microbial growth. Alternately, the minerals could be colonized by biofilms that derive their energy from other sources. The latter is possible because the rock surfaces interface with active ecosystems. The constituents of the microbial communities have not been identified, leaving doubt as to whether mineral transformations are coupled to the activity of specialized microbial communities.

Microbial identification commonly limits investigations in microbial ecology because many bacterial species cannot be grown in culture. The introduction of molecular methods to microbial ecology has encouraged the study of communities of organisms that are not culturable (Ward et al., 1992; Giovannoni and Cary, 1993). The 16S ribosomal RNA genes have played a pivotal role in these investigations. Ribosomal RNA databases include sequences from more than 1000 strains of Bacteria (eubacteria) and Archaea (archaebacteria), making it possible to accurately identify unknown genes by phylogenetic methods. When genes from novel organisms are encountered in these investigations, phylogenetic information commonly indicates biochemical potential. For example, organisms such as methanogens, sulfur-and iron-reducing bacteria, and extreme thermophiles can be identified by characteristic signatures in ribosomal RNA genes. Furthermore, ribosomal RNA gene sequences can be used to construct oligonucleotide probes that hybridize specifically to the nucleic acids of target organisms. Probes of this type are used for the microscopic identification of microorganisms and to measure the abundance of specific target sequences in mixtures of nucleic acids that have been extracted from natural systems (Stahl et al., 1988; DeLong et al., 1989).

Our first objectives were to confirm and extend the observations of Furnes and colleagues (this volume), who found evidence of DNA within the glass-alteration interface of basaltic glass and showed that elements consistent with microbial life were concentrated in the alteration products from Ocean Drilling Program (ODP) Hole 896A, drilled during Leg 148. Fluorescence imaging studies with three dif- 


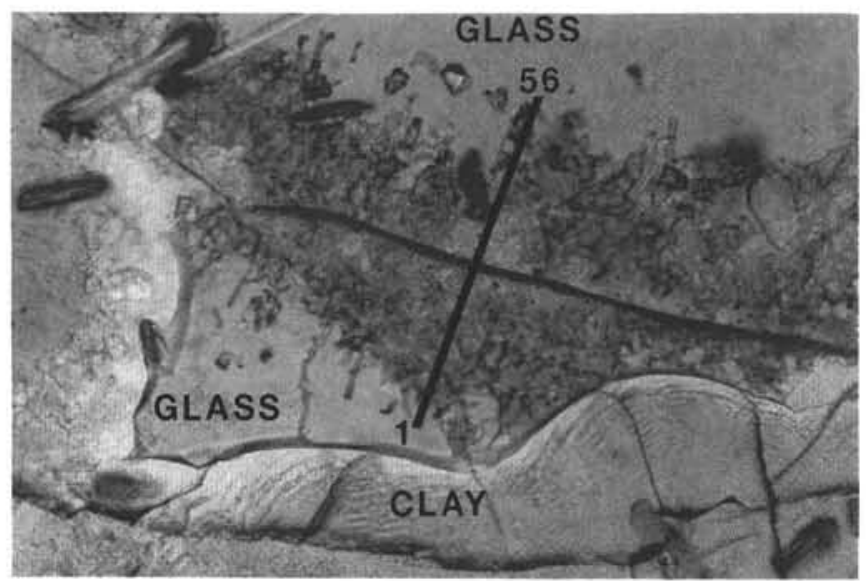

Figure 1. Photomicrograph of Sample 148-896A-12R-1, 4-7 cm (Piece 1) in plane-polarized light. The top of the photomicrograph is fresh glass with rare olivine and plagioclase microlites. The left and bottom of the photomicrograph (with fingerprint texture with fractures) is secondary clay. A black fracture through the glass is surrounded by etch pits and tracks. The straight black line with " 1 " at the bottom and " 56 " at the top is the profile that was analyzed by microprobe, with the first analysis point at the bottom. The length of the profile is $285 \mu \mathrm{m}$. The microprobe data are presented in Figure 2.

ferent DNA-binding dyes, electron microprobe analyses, and results from a hole at a second site, Deep Sea Drilling Project (DSDP)/ODP Hole 504B, all support the conclusion that microorganisms were present in the glass/alteration interface of these basaltic glass samples. Our second objective was to extract microbial DNA from rocks for genetic studies.

Hole $896 \mathrm{~A}$ was drilled in $3440 \mathrm{~m}$ of water $600 \mathrm{~km}$ east-northeast of the Galapagos Islands in the eastern equatorial Pacific (Shipboard Scientific Party, 1993). It is $1100 \mathrm{~m}$ south and $700 \mathrm{~m}$ east of Hole $504 \mathrm{~B}$, which is the deepest hole drilled in the oceanic crust. In Hole $896 \mathrm{~A}$ volcanic rocks were recovered from depths of 195.1 to $469 \mathrm{~m}$ below seafloor (mbsf). The rocks are primarily basalts that erupted into seawater to form pillow basalts with quenched glass on their exterior. Some intrusive basalts (dikes) and basalt breccias were also recovered. At this site, $179 \mathrm{~m}$ of sediment insulates the volcanic rocks from the seawater, so at the sediment/volcanic basement interface, the temperature is about $50^{\circ} \mathrm{C}$.

\section{SAMPLES AND METHODS Samples}

Three samples from Hole 896A and Hole 504B from the Costa Rica Rift were used for this study. The two samples from Hole 896A were collected during Leg 148 and the sample from Hole 504B was collected during Leg 70 of DSDP.

Sample 148-896A-7R-1, 52-55 cm (Piece 10), from $247.92 \mathrm{mbsf}$ is a basalt pillow margin at the base of petrologic unit 13 (Shipboard Scientific Party, 1993). At 250 mbsf the temperature is estimated to be about $60^{\circ} \mathrm{C}$ (Shipboard Scientific Party, 1993). The sample has a $1-\mathrm{cm}$ glass rim that contains about $5 \%$ plagioclase phenocrysts and $1 \%$ olivine phenocrysts. The glass has been partially replaced with palagonite, the zeolites phillipsite and possibly chabazite, and 1- to 5$\mu \mathrm{m}$ grains of pyrite. Where fractures penetrate the glass, the glass is typically altered to clay, and along the boundary between the glass and the clay we observed irregular pits and channels that we suspected were produced by microbes (Fig. 1). This shipboard thin section was stained with a dye that indicates the presence of DNA.
Sample 148-896A-12R-1, 4-7 cm (Piece 1), from $295.64 \mathrm{mbsf}$ is a hyaloclastite breccia within Unit 16 that is cemented with carbonate. At $295 \mathrm{mbsf}$ the temperature of the hole is about $70^{\circ} \mathrm{C}$. About $80 \%$ of the glass in the breccia has been replaced with clay, but where glass is still present, alteration along cracks in the glass is similar to that observed in Sample 7R-1, 52-55 cm. This alteration is amorphous and is associated with channels that appear to be etched in the glass and extend from the crack into the glass. The morphology of the channels and pits have been described in detail elsewhere in this volume (Furnes et al., this volume). Oxidized secondary minerals occur between the glass and crystalline basalt (Shipboard Scientific Party, 1993), and $1-\mu \mathrm{m}$ sulfide grains are present in the altered glass, which suggests that both oxidized and reduced conditions exist within a few millimeters of each other. Six thin sections were made from this sample for microprobe analysis and for staining with dyes that bind with DNA.

The third sample (70-504B-48R-2) was examined in thin section and also had fractures surrounded with pits and channels. The remainder of the sample was crushed in an attempt to extract DNA from the fractures.

\section{Thin-section Preparation}

A single thin section that was prepared aboard ship was used for our study of Sample 148-896A-7R-1, 52-55 cm (Piece 10). Six thin sections of Sample 148-896A-12R-1, $47 \mathrm{~cm}$ (Piece 1) were prepared at the Smithsonian Institution using techniques that were expected to preserve biological material in the rocks-no water or ultrasonic cleaners or high temperatures were used. The sample was obtained from the curated collection of ODP cores at Texas A\&M University, vacuum impregnated with Epo-tek 301 epoxy, and cured overnight at room temperature. The sample was then cut in half with a diamond saw that was lubricated and cooled with Texaco almag oil and rinsed in 1-1-1 trichloroethane. After being polished on a 600-mesh diamond wheel that was lubricated with alcohol ( $95 \%$ ethanol), the surface was glued to a glass slide with Epo-tek 301. The rock was cut from the glass slide using a diamond saw, leaving a 0.5 -mm-thick wafer of rock attached to the slide, which was polished with $6-\mu \mathrm{m}$ diamond paste and then with $1-\mu \mathrm{m}$ diamond paste. The thin sections were swabbed with alcohol to remove the paste.

\section{Electron Microprobe}

Ten-element chemical analyses of the glass, etch pits, and channels were done with the nine-spectrometer ARL microprobe at the Smithsonian Institution Division of Mineral Sciences. The standard used for the calibration were VG-2 (USNM 111240/52) for $\mathrm{SiO}_{2}$, $\mathrm{Al}_{2} \mathrm{O}_{3}, \mathrm{FeO}, \mathrm{MgO}$, and $\mathrm{CaO}$. The standard for $\mathrm{P}_{2} \mathrm{O}_{5}$ was apatite (US$\mathrm{NM}$ 104021), for $\mathrm{MnO}$ was manganite, for $\mathrm{Na}_{2} \mathrm{O}$ was Kakanui anorthoclase (USNM 133868), and for $\mathrm{K}_{2} \mathrm{O}$ and $\mathrm{TiO}_{2}$ was Kakanui hornblende (USNM 143965). Counting time was $10 \mathrm{~s}$ on each element and backgrounds for all elements except $\mathrm{SiO}_{2}$ were calculated based on the background values for the elements on pure $\mathrm{SiO}_{2}$. The background for $\mathrm{SiO}_{2}$ was based on the background at the $\mathrm{Si}$ peak position on pure $\mathrm{Al}_{2} \mathrm{O}_{3}$. Standard glass A-99 (Jarosewich et al., 1980) was analyzed to check the calibration (Fisk et al., this volume).

\section{Staining and Epifluorescence Microscopy}

Three dyes were used to stain separate thin sections. Hoechst 33342 was used on Sample 148-896A-7R-1, 52-55 cm, and POPRO-3 and Sytol1 were used on Sample 148-896A-12R-1, 0-4 cm. These dyes bind specifically to nucleic acids-Hoechst 33342 and POPRO-3 to DNA and Sytol1 to DNA and RNA. Three dyes were used because they fluoresce at different wavelengths (Hoechst 33342 is blue, PO-PRO-3 is orange, and Sytoll is green) and therefore elimi- 
nate the possibility that fluorescence observed in the thin sections is from minerals within the thin section or materials used in preparing the sections. Dyes were obtained from Molecular Probes Inc., Eugene, OR.

For each dye the staining procedure was slightly different. Sample 148-896A-7R-1, 52-55 cm, was stained for $1 \mathrm{hr}$ at $37^{\circ} \mathrm{C}$ in Hoescht $33342,1 \mu \mathrm{g} / \mathrm{mL}$ in $0.2 \mathrm{X} \mathrm{SSPE}$ buffer, destained for $10 \mathrm{~min}$ at $37^{\circ} \mathrm{C}$ in 0.2 XSPE ( 1 X SSPE: $0.18 \mathrm{M} \mathrm{NaCl}, 10 \mathrm{mM} \mathrm{NaPO}_{4}, \mathrm{pH} 7.2,1 \mathrm{mM}$ ethylene diamine tetra-acetic acid [EDTA]), and mounted in $0.2 \mathrm{X}$ SSPE.

Thin sections of Sample 148-896A-12R-1, 0-4 cm, were fixed and dehydrated to permeabilize cells to DNA dyes. This was accomplished by immersing sections in a 1:4 mixture of formalin and $50 \%$ ethyl alcohol for $10 \mathrm{~min}$, followed by dehydration for $10 \mathrm{~min}$ in $80 \%$ ethanol, $10 \mathrm{~min}$ in $100 \%$ ethanol, and drying in air at room temperature. Thin section number 3 of Sample 148-896A-12R-1, 0-4 cm, was stained with the cyanine dye PO-PRO-3 at a concentration of 10 $\mathrm{mM}$ in TE buffer (10 mM Tris $\times \mathrm{HCl}, \mathrm{pH} 8.0,1 \mathrm{mM}$ EDTA). This section was stained for $30 \mathrm{~min}$, followed by washing for $30 \mathrm{~min}$ at room temperature in TE buffer, and mounting in Citifluor (Citifluor LTD, London).

Thin section number 5 of Sample 148-896A-12R-1, 0-4 cm, was stained for $15 \mathrm{~min}$ at room temperature with a $50-\mathrm{mM}$ solution of the dye Sytoll in TE buffer, followed by $5 \mathrm{~min}$ of washing. The section was then air dried and mounted.

The dyed sections were examined at $400 \times$ and $1000 \times$ magnifications using a Zeiss Standard 18 epifluorescence microscope equipped with a mercury vapor excitation source. The dyes and filter sets were as follows: Hoescht 33342 , excitation band pass 365 , dichroic mirror FT395, barrier long pass LP397; PO-PRO-3, excitation band pass 540, dichroic mirror FT 605, barrier long pass $565 \mathrm{~nm}$; Syto 11, excitation band pass 480, dichroic mirror FT 505, barrier long pass 535 $\mathrm{nm}$. After photographing the fluorescence produced by the incident ultraviolet light, thin section 3 of Sample 148-896A-12R-1, 0-4 cm, was treated with $50 \mu \mathrm{g} / \mathrm{mL}$ DNase I (a DNA-degrading enzyme; Sigma, St. Louis, MO) for $24 \mathrm{hr}$.

\section{DNA Extractions}

Two samples (70-504B-48-2, 120-124 cm, and 148-896A-12R-1, $0-4 \mathrm{~cm}$ ) were treated to remove contaminating DNA from rock surfaces. Single pieces of rock ( $2.5 \mathrm{~g}$ and $12.4 \mathrm{~g}$, respectively) were first irradiated with ultraviolet light $\left(\lambda_{\max }=254 \mathrm{n}\right)$ at $400 \mathrm{~J} / \mathrm{m}^{2}$ per side, with rotation of the rock 6 times to irradiate each side. This level of irradiation is sufficient to cause approximately one thymidine dimer pair to form per 100 base pairs of DNA (Setlo, 1966), and thus render surface-contaminating DNA inactive to replication by DNA polymerases. Surface irregularities of the rocks might protect contaminating DNA in cells from damage from ultraviolet irradiation. To remove possible cell contaminants from rock surfaces, therefore, the samples were tumbled for $20 \mathrm{~min}$ in a DNA-free rock tumbler in the presence of dry, coarse, carborundum grit that had been baked at $220^{\circ} \mathrm{C}$ for $48 \mathrm{hr}$ to destroy macromolecular contaminants, including DNA. Using forceps that had been heated to eliminate contaminating DNA, the rocks were removed and placed in sterile plastic ware. Rocks were crushed to sand using a mortar and pestle in a laminar flow hood. Organic material was extracted in lysis buffer that contained high salt and EDTA concentrations ( $100 \mathrm{mM}$ EDTA, $400 \mathrm{mM}$ $\mathrm{NaCl}, 0.75 \mathrm{M}$ sucrose, and $50 \mathrm{mM}$ Tris $\times \mathrm{HCl} \mathrm{pH} 9.0$ ). Proteins were degraded with proteinase $\mathrm{K}$, releasing DNA. The detergent sodium dodecyl sulfate was added to $1 \%$ and proteinase $\mathrm{K}$, an enzyme that hydrolyzes proteins, was added to $100 \mathrm{mg} / \mathrm{mL}$, followed by incubation at $37^{\circ} \mathrm{C}$ for $30 \mathrm{~min}$, then $55^{\circ} \mathrm{C}$ for $10 \mathrm{~min}$. Lysate was transferred to polypropylene centrifuge tubes, extracted with an equal volume of phenol/chloroform/isoamyl alcohol (25/24/1), and again extracted with an equal volume of $\mathrm{CHCl}_{3} / \mathrm{IAA}(24 / 1)$. The purified nucleic ac- ids were precipitated with 2 volumes of $100 \%$ ethanol, 0.1 volume 2 $\mathrm{M}$ sodium acetate $\mathrm{pH} 5.2$, and resuspended in aqueous solution.

\section{Polymerase Chain Reaction}

Several sets of small subunit ribosomal DNA primers were used to examine rocks for the presence of microbial genomic DNA. The bacterial primer $27 \mathrm{~F}$ and the universal $16 \mathrm{~S}$ ribosomal DNA primer $1492 \mathrm{R}$ were used to selectively amplify a $1.4-\mathrm{kb}$ fragment of bacterial 16S ribosomal RNA genes (Giovannoni, 1991). The Arch21F and the universal $1492 \mathrm{R}$ primer were used to selectively amplify the same DNA region from Archaea (Giovannoni et al., 1988). These two primer sets specifically amplify 1.4-kb regions from prokaryotes of the Archaea and Bacteria domains, respectively. Universal small subunit ribosomal DNA primers (1492R and 519F; Lane, 1991) were used to amplify ribosomal DNAs from rock extracts using polymerase chain reaction (PCR). Reactions contained $1 \%$ of the rock extract, $5 \%$ acetamide, $200 \mathrm{nM}$ of each primer, $1.5 \mathrm{mM} \mathrm{MgCl}_{2}, 200 \mu \mathrm{M}$ total nucleotide triphosphates, IX Taq reaction buffer containing 500 $\mathrm{mM} \mathrm{KCl}, 100 \mathrm{mM}$ Tris $\times \mathrm{HCl} \mathrm{pH} \mathrm{9.0,} \mathrm{and} \mathrm{1 \%} \mathrm{TritonX-100} \mathrm{(Promega}$ Corporation, Madison, WI), and 2.5 units Taq DNA polymerase (Promega) in a volume of $100 \mathrm{~mL}$. Thirty-five cycles were performed in a thermocycler (MJ Research, Watertown, MA) using the following conditions: denaturation at $94^{\circ} \mathrm{C}$ for $1 \mathrm{~min}$, annealing at $55^{\circ} \mathrm{C}$ for $1 \mathrm{~min}$, and elongation at $72^{\circ} \mathrm{C}$ for $3 \mathrm{~min}$. Unreacted oligonucleotides and deoxynucleotide triphosphates were removed using a Qiaquickspin PCR purification kit (Qiagen, Chatsworth, CA).

\section{Oligonucleotide Probe Hybridization}

An oligonucleotide probe specific for Archaea (915R; Stahl and Amman, 1991) was hybridized to PCR amplification products. The 5 prime terminus of the probe $(0.5 \mathrm{mg})$ was labeled with $100 \mathrm{mCi}$ of $[\gamma-$ $\left.{ }^{32} \mathrm{P}\right]$-dATP (New England Nuclear Corp., Boston, MA) using T4 polynucleotide kinase (Promega) as previously described (Giovannoni et al., 1988). For dot blots $100 \mathrm{ng}$ of each PCR amplification product was denatured in $0.2 \mathrm{M} \mathrm{NaOH}$ and applied to Zetaprobe membranes (Bio-Rad Laboratories, Richmond, CA) using a dot blot manifold (Minifold I SRC 096/90: Schleicher \& Schuell, Keene, $\mathrm{NH}$ ). The membranes were dried at $80^{\circ} \mathrm{C}$ for $15 \mathrm{~min}$ and UV crosslinked $\left(120 \mathrm{~J} / \mathrm{m}^{2}\right)$ in an ULTRA LUM UV radiation source. Membranes were prehybridized for $15 \mathrm{~min}$ at room temperature in $10 \mathrm{~mL}$ of hybridization buffer ( $1 \mathrm{mM}$ EDTA, $0.5 \mathrm{mM} \mathrm{NaH}_{2} \mathrm{PO}_{4} \mathrm{pH} 7.2,7 \%$ SDS). The solution was replaced with $6 \mathrm{~mL}$ of fresh buffer containing $5 \mathrm{ng}$ of $\gamma^{-32} \mathrm{P}$-labeled DNA probe, and the membranes were incubated at room temperature for $18 \mathrm{hr}$. Membranes were washed in two changes of wash buffer $(0.2 \mathrm{XSSP}, 0.1 \% \mathrm{SDS})$ at room temperature for $15 \mathrm{~min}$. A final stringency wash was done at $45^{\circ} \mathrm{C}$ for $30 \mathrm{~min}$. Hybridization of the probe was detected with X-ray film.

\section{RESULTS Electron Microprobe}

A profile of 56 chemical analyses across a fracture and the surrounding etched glass is shown in Figures 1 and 2. The first nine analyses and the last five analyses in the profile are of fresh glass and appear to be unaffected by the processes that produced the pits and etch trails. This fresh glass is chemically similar to other glass found at this depth in the hole (Fisk et al., this volume). Within the area of etched pits and channels, the composition of the glass is highly variable (Fig. 2), which suggests that the processes that are affecting the glass are operating on a scale of less than $2 \mu \mathrm{m}$ - the beam diameter of the microprobe analyses.

Several differences between fresh and altered glass are evident. $\mathrm{Al}_{2} \mathrm{O}_{3}$ and $\mathrm{K}_{2} \mathrm{O}$ are significantly enriched in that altered glass, and 

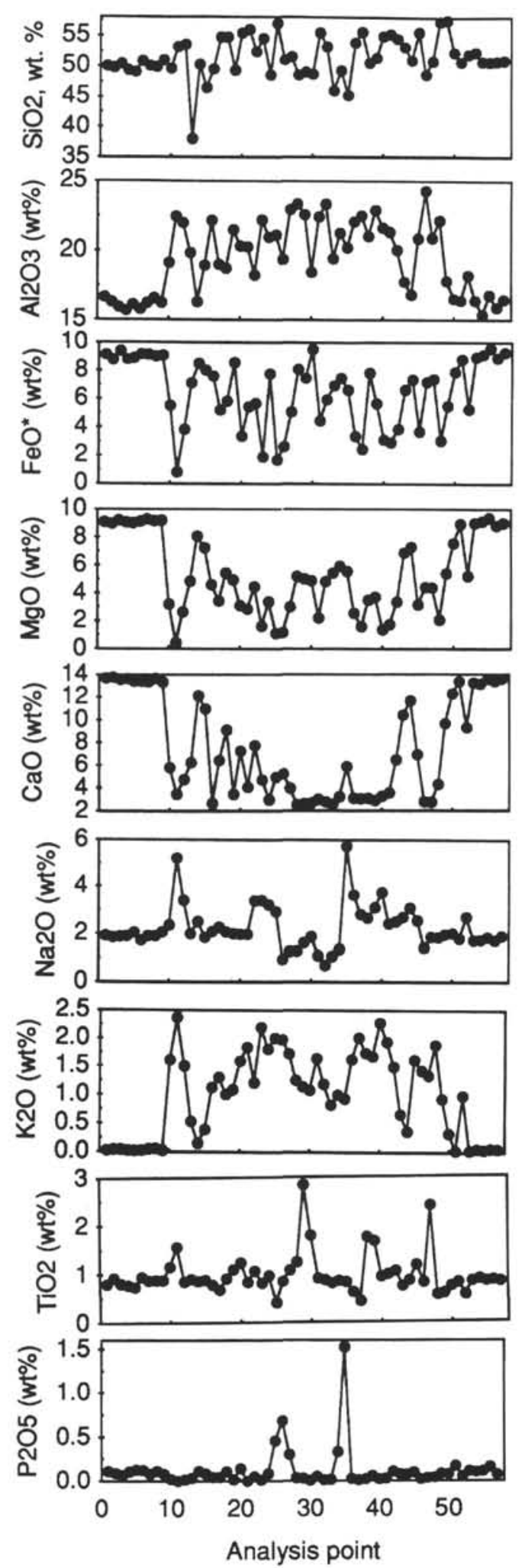

Figure 2. Electron microprobe data along profile 1-56 (shown in Fig. 1), Sample 148-896A-12R-1, 4-7 cm (Piece 1). Analysis point 1 is at the bottom of the profile. Analysis points $1-9$ and $51-56$ are fresh glass. Analysis point 31 coincides with the fracture. The microprobe analyses were spaced $5.1 \mu \mathrm{m}$ apart and the length of the profile is $285 \mu \mathrm{m}$.
$\mathrm{FeO}, \mathrm{MgO}$, and $\mathrm{CaO}$ are significantly lower in the altered glass than in the fresh glass. These differences indicate that the glass is being broken down and that $\mathrm{FeO}, \mathrm{MgO}$, and $\mathrm{CaO}$ are being preferentially removed from the altered glass. The sink for the $\mathrm{CaO}$ could be the calcium carbonate that cements the fragments of this breccia. Both $\mathrm{FeO}$ and $\mathrm{MgO}$ may be taken up by clays, as the clay in Hole 504B has $15 \%$ to $20 \% \mathrm{FeO}$ and $18 \%$ to $24 \% \mathrm{MgO}$ (Noack et al., 1983; Alt et al., 1985).

There are several significant correlations between elements within the profile. For example, high $\mathrm{K}_{2} \mathrm{O}$ is associated with high $\mathrm{Al}_{2} \mathrm{O}_{3}$ and low $\mathrm{MgO}, \mathrm{MnO}$, and $\mathrm{FeO}$ are also strongly correlated. $\mathrm{Al}_{2} \mathrm{O}_{3}$ has a strong negative correlation with $\mathrm{MgO}, \mathrm{FeO}$, and $\mathrm{CaO}$, which may result from the immobility of $\mathrm{Al}$ relative to $\mathrm{Mg}, \mathrm{Fe}$, and $\mathrm{Ca}$ during the breakdown of the glass. $\mathrm{Na}_{2} \mathrm{O}, \mathrm{TiO}_{2}$, and $\mathrm{P}_{2} \mathrm{O}_{5}$ are not strongly correlated with other elements in the chemical profile (Fig. 2). For $\mathrm{Na}$ and $\mathrm{P}$, this may be due their high solubility and mobility in the fracture, but $\mathrm{Ti}$ is considered insoluble and immobile so reason for the absence of a correlation with $\mathrm{Al}$ is not clear.

\section{Staining and Epifluorescence Microscopy}

The dyes used in these experiments form complexes with greatly enhanced fluorescence quantum yields after binding specifically to DNA and/or RNA. The fluorescence quantum yield of Sytoll increases approximately 10 -fold after binding to DNA or RNA. The cyanine dye PO-PRO-3 exhibits a 20- to 200-fold increase in fluorescence upon binding to DNA. Hoescht 33342 binds specifically to adenine/thymidine-rich regions in the minor groove of DNA, with a 30 -fold increase in fluorescence (Kapuscinski, 1990). The intensities observed (Fig. 3) are not caused by background fluorescence of the uncombined dye, which was checked by examining areas of the thin section that were free of cracks but where dye was present. Rock samples were studied by fluorescence microscopy before staining, and it was determined that the samples exhibited weak fluorescence in the blue and green regions of the spectrum without staining; however, no autofluorescence of rocks was observed in the orange and yellow parts of the spectrum.

The thin sections of Sample 148-896A-7R-1, 52-55 cm (Piece 10) were stained using PO-PRO-3 and Sytol1, two dyes with high affinities for nucleic acids and enhanced fluorescence yields in the presence of nucleic acids. The dyes indicated that DNA was present, but of the two, PO-PRO-3, which exhibits an orange fluorescence upon binding to DNA, was the most informative.

Hoescht 33342 was used to stain one thin section from Hole 896A (PI. 1, Fig. 1). Hoescht 33342 binds specifically to the minor groove of DNA molecules, with a resulting enhancement of fluorescent quantum yield in the blue region of the spectrum. Hoescht dyes are similar to DAPI, which was used by Furnes and coworkers (this volume) to indicate the presence of DNA in Sample 148-896A-11R-1, 73-75 cm, but are somewhat more specific to DNA and usually less bright. One drawback of Hoescht 33342 was the presence of blue autofluorescence in unstained rock. This background autofluorescence was generally more uniform in appearance and less bright than the fluorescence associated with regions of alteration after staining with Hoescht 33342 . However, significant blue autofluorescence of very uniform appearance was commonly associated with cracks in the sections, leading us to seek additional DNA stains with emission maxi$\mathrm{ma}$ in parts of the spectrum that are not subject to interference from autofluorescence.

The orange fluorescence of PO-PRO-3 was confined primarily to regions of rock alteration. Basaltic glass exhibited almost no POPRO 3 staining (PI. 1, Fig. 2). Staining of channels was vivid and decreased inward from the glass/alteration interface toward the fracture. The intensity of staining with PO-PRO-3 was consistent with the presence of DNA, but less than the fluorescence observed in control experiments with intact bacterial cells, suggesting that the DNA present in the rock preparations was partially degraded. Cell-like 
structures of approximately $1 \mathrm{~mm}$ diameter were occasionally observed, but in general cellular morphologies could not be discerned. Fractal-like structures elsewhere in the rock did not stain, nor did particulates associated with the rock or cracks in the rock. DNase treatment resulted in a decrease in fluorescence, but fluorescence was not eliminated. In control experiments, $E$. coli cells treated with DNase I lost most of their PO-PRO-3 fluorescence. The limited effect of DNase I on rock sections stained with PO-PRO-3 may be attributed to the poor penetration of DNase $\mathrm{I}$ into the channels and pits where the fluorescence was strongest. The diffusion of DNase I through clay alteration products may be limited by its molecular weight ( 31,000 daltons), which is much greater than that of the dyes used in these experiments $(<1000$ daltons $)$.

With Syto 11, as with the other dyes, significant staining of channels and alteration products was observed. However, with Sytoll, other structures within the rock, including particulate matter, were also stained brightly (Pl. I, Figs. 3, 4). A combination of interference from autofluorescent particles and endogenous green fluorescence of the rock rendered the signal from Sytoll somewhat equivocal, but nonetheless consistent with the possibility that DNA is present in channel regions and alteration products. In summary, all three nucleic acid dyes revealed evidence of DNA in basaltic glass alteration products and supported the highest concentrations of DNA at interfaces between basaltic glass and alteration products, particularly in channels.

\section{DNA Extractions}

DNA was extracted from Samples 70-504B-48-2, 120-124 cm, and 148-896A-12R-1, 0-4 cm, using procedures that were developed for the isolation of DNA from natural samples. A major concern was the possibility that rock samples were contaminated with DNA from drilling muds, seawater, or handling after retrieval. To minimize the possibility of carrying contaminating DNA forward into DNA extraction protocols, samples were decontaminated as described above. Control experiments indicated that extractions performed by the same procedure in the absence of rock were not contaminated with detectable DNA as assayed by polymerase chain-reaction amplifications of ribosomal RNA genes. However, extracts of rock samples did contain ribosomal RNA genes that could be amplified.

\section{Polymerase Chain Reaction}

Several different sets of oligonucleotide primers for small subunit ribosomal RNA genes were used to examine rocks for the presence of microbial genomic DNA. The oligonucleotide primer sets used were of three types, either universal for all cells, specific for the Bacteria, or specific for the Archaea. Small subunit ribosomal RNA genes are about 1540 bases in length. The universal primers we employed span an internal region of the gene which is about 1000 bases long. Both of the specific sets of primers we used span nearly the entire gene, approximately 1400 bases. Positive results indicating the presence of ribosomal DNA genes were obtained only with the universal primers. Neither set of specific primers yielded products from rock extracts in amplification reactions.

The universal ribosomal RNA primers 1492 reverse and 536 forward were successfully used to amplify a 1-kb segment from both rock samples (Fig. 3). The amplified DNA is probably microbial in origin because eucaryotic ribosomal RNA genes are significantly larger for the same domain and are thus easily detectable by agarose gel electrophoresis.

Two factors may explain the amplification of these shorter DNA regions with universal primers. Smaller DNA target regions often amplify more efficiently. This phenomenon is enhanced considerably when low molecular weight DNA is used as a template. Thus, both the fluorescence data and the PCR data can be interpreted as evidence for partially degraded DNA in rock samples.

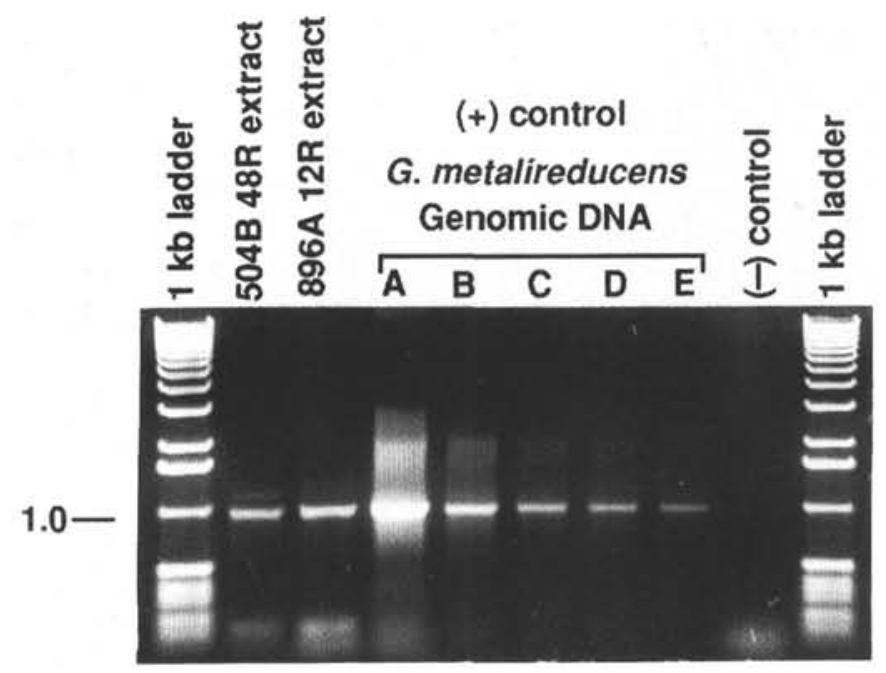

Figure 3. Photograph of agarose gel that was used to separate DNA products by molecular weight after they were extracted from the rocks and amplified by the polymerase chain reaction. The agarose gel was stained with the fluorescent dye ethidium bromide. The lines labeled 504B 48R EXTRACT and 896A 12R EXTRACT indicate the presence of DNA that is 1000 base pairs long $(1.0 \mathrm{~kb})$ in the extracts of Samples 70-504B-48R-2, 120-124 cm, and 148-896A-12R-1, 0-4 cm. Genomic DNA from the bacterium Geobacter metallireducens was used as a positive $(+)$ control (A, I ng: B, $200 \mathrm{pg}$ : C, 100 pg; D, $70 \mathrm{pg}$; and E, $50 \mathrm{pg}$ ). The negative (-) control consisted of the same reagents with distilled water in place of extract. One percent of the rock extract was added to the PCR reactions, which corresponds to an extract of 25 $\mathrm{mg}$ of rock from Hole 504B, and from $62 \mathrm{mg}$ of rock from Hole $896 \mathrm{~A}$. The DNAs flanking the experimental amplification reaction products are molecular-weight size standards (1 kb DNA ladder, Bethesda Research Laboratories). The band marked 1.0 is a piece of DNA that is 1000 base pairs long.

\section{Oligonucleotide Probe Hybridization}

The amplified DNA products of polymerase chain reactions were blotted against the 915R Archaea probe (Stahl and Amman, 1991) that had been radioactively labeled with ${ }^{32} \mathrm{P}$. No hybridization of the probe to amplified fragments was observed; however, controls hybridized as predicted (data not shown). We conclude that a majority of the amplified genes from rock extractions were probably bacterial in origin.

\section{DISCUSSION}

\section{Electron Microprobe}

The chemical differences of the fresh glass and the associated etch pits and tracks (Figs. 1,2) are clearly not the same as chemical changes caused by secondary alteration of basalt glass. For example, previously reported palagonite in Sample 70-504B-4R-5, 87-89 cm, has less $\mathrm{SiO}_{2}$ and $\mathrm{Na}_{2} \mathrm{O}$, more $\mathrm{MgO}$ and $\mathrm{FeO}$, and about the same $\mathrm{Al}_{2} \mathrm{O}_{3}$ as the glass from which it formed (Noack et al., 1983). The area affected by secondary processes in Sample 148-896A-12R-1, 4-7 cm, however, shows no significant change in $\mathrm{SiO}_{2}$, a slight increase in $\mathrm{Na}_{2} \mathrm{O}$, significant decreases in $\mathrm{FeO}, \mathrm{MgO}$, and $\mathrm{CaO}$, and a significant increase in $\mathrm{Al}_{2} \mathrm{O}_{3}$ relative to the surrounding glass.

The secondary minerals that are prevalent at Hole 896 A are smectite clays, iron hydroxides, aragonite (and some calcite), zeolite (phillipsite) and pyrite (Shipboard Scientific Party, 1993). None of these minerals have chemistries that could account for the chemical differences between the fresh and altered glass. Furthermore, these miner- 


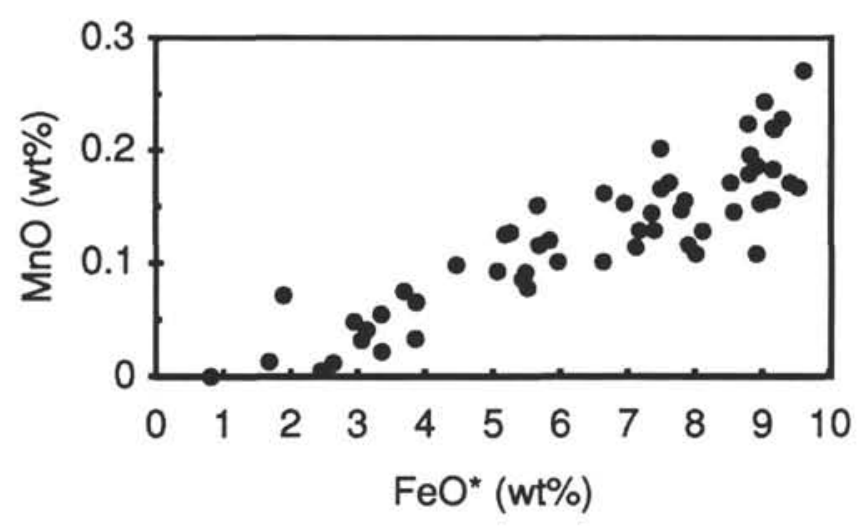

Figure 4. Oxide variation diagram of electron microprobe analyses of $\mathrm{FeO}$ and $\mathrm{MnO}$ in the area shown in Figure 1 (Sample 148-896A-12R-1, 4-7 cm. Piece 1).

als are not observed in the amorphous area around the fracture (Fig. 1). The chemistry around the fracture indicates that none of these minerals is present, even as submicroscopic grains.

The experimental alteration of oceanic basaltic glass by seawater at $70^{\circ} \mathrm{C}$ and $1-$ atm pressure results in the loss of $\mathrm{Si}$ and $\mathrm{Ca}$ from the glass and the uptake of $\mathrm{Mg}$ by the glass (Seyfried and Bischoff, 1979). At $150^{\circ} \mathrm{C}$ and 500 bars the effects are similar but accelerated. The clay produced in the $150^{\circ} \mathrm{C}$ experiment is high in $\mathrm{Mg}$ and low in $\mathrm{Si}$ and $\mathrm{Ca}$ relative to the original glass and is similar to clays that are the natural alteration products of basalt glass (Melson and Thompson, 1973) although not all clays are as high in $\mathrm{Al}$ and low in $\mathrm{Mg}$ as these. The clays produced in the experiments, however, are distinctly different from the areas of alteration analyzed by the microprobe in Sample 148-896A-12R-1, 0-4 cm. This suggests that the form of alteration observed in the ODP samples in this study is different from the chemical alteration of basaltic glass to form clay that has been extensively described in the literature.

The high $\mathrm{K}_{2} \mathrm{O}$ of the altered glass associated with "microbial" pits and tracks is interesting because the alteration of $\mathrm{K}_{2} \mathrm{O}$-poor basalt glass results in clays that are also $\mathrm{K}_{2} \mathrm{O}$-poor. $\mathrm{K}_{2} \mathrm{O}$-rich minerals form in Hole 504B but they are associated with veins and the rare replacement of plagioclase feldspar with K-rich feldspar. Where K-rich clays exist, they always have less than $10 \% \mathrm{Al}_{2} \mathrm{O}_{3}$, but as stated above, in the altered sections of the samples that we studied there is a strong correlation of $\mathrm{K}_{2} \mathrm{O}$ with $\mathrm{Al}_{2} \mathrm{O}_{3}$, and $\mathrm{Al}_{2} \mathrm{O}_{3}$ reaches 22 wt \%.

The elevated $\mathrm{P}_{2} \mathrm{O}_{5}$ in some areas of the altered glass is interesting because it has been recognized for some time that the submarine weathering of basalt results in an increase in the $\mathrm{P}_{2} \mathrm{O}_{5}$ content of the basalt (Miyashiro et al., 1969; Hart, 1970). This $\mathrm{P}_{2} \mathrm{O}_{5}$ increase during weathering is interesting in light of the fact that seawater is extremely low in phosphate (about $3 \times 10^{-6} \mathrm{~mol} / \mathrm{L}$ at $2000 \mathrm{~m}$ depth). The sink for phosphorus in the basalts appears to be calcium carbonate in veins that may have as much as $0.8 \mathrm{wt} \% \mathrm{P}_{2} \mathrm{O}_{5}$ (Laverne, 1983). The areas within Sample 148-896A-12R-1, 0-4 cm, that are high in phosphorus are not elevated in calcium, which indicates that carbonate is not forming in the areas of altered glass. Elevated phosphorus in this area occurs in the microprobe analyses with the lowest total oxides, which suggests additional elements were present that were not analyzed. These could be hydrogen and oxygen in water, carbon, nitrogen, sulfur, or chlorine. In future analyses we will quantify the amount of oxygen, sulfur, and chlorine.

An additional feature of the microprobe analyses is the strong correlation of $\mathrm{FeO}$ and $\mathrm{MnO}$ (Fig. 4). During the process of alteration of the glass in the area shown in Figure 1 both $\mathrm{FeO}$ and $\mathrm{MnO}$ are removed from the glass (Fig. 4, $\mathrm{FeO}-\mathrm{MnO}$ ). This is interesting because both $\mathrm{Fe}$ and $\mathrm{Mn}$ occur primarily in their reduced state $\left(\mathrm{Fe}^{2+}\right.$ and $\left.\mathrm{Mn}^{2+}\right)$ in basalt glass and in their oxidized state $\left(\mathrm{Fe}^{3+}\right.$ and $\left.\mathrm{Mn}^{4+}\right)$ in seawater, and the oxidation of $\mathrm{Fe}$ and $\mathrm{Mn}$ is a possible energy source for the diagenesis of organic matter in marine sediments (Froelich et al., 1979).

\section{CONCLUSIONS}

Rock cores are among many scientific samples that cannot be manipulated to the complete satisfaction of investigators. In the case of the basalt cores that were the principal subject of this investigation, a major concern is that contamination occurred during the recovery process. It may never be possible to rule out this possibility, absolutely, with a single experiment. Therefore, our approach was to develop several lines of experimental evidence that can provide evidence for or against the presence of microbial life at interfaces between basaltic glass and alteration products.

Two experimental approaches were used to examine basaltic glass samples for the presence of DNA. In the first set of experiments, fluorescent stains, which exhibit enhanced fluorescence when bound to nucleic acids, were used to localize nucleic acids, and particularly DNA, in thin sections of basaltic glass. In the second set of experiments, basaltic glass samples were surface-treated to remove contaminating DNA, crushed, and organic material extracted to chemically isolate any nucleic acids that might be present. Both sets of experiments indicated the presence of DNA in basaltic glass samples. Because the amounts of DNA extracted from rock samples were too small to be chemically measured by direct means, a genetic assay, gene amplification by the polymerase chain reaction, was used to detect ribosomal RNA genes in extracts.

Using this method, ribosomal RNA genes were recovered from rock extracts. The nucleotide sequencing of these ribosomal RNA genes is presently in progress. The results of that analysis will reveal the evolutionary relationships of the cloned genes. It is likely that the identification of these gene clones will influence our perceptions of the origins of these genes. If these genes represent novel microorganisms, or show phylogenetic affinities with known metal-oxidizing groups of bacteria associated with geochemical processes, then the results will be interpreted as strong support for the rock origin of the DNA. If, on the other hand, the cloned genes reveal affinities to organisms commonly associated with humans or seawater, then contamination will seem a likely source.

Finally, electron microprobe analysis of areas of enhanced fluorescence showed that phosphorus and potassium (two elements consistent with the presence of life) were present in high abundance (analyses of $\mathrm{C}$ and $\mathrm{N}$ by microprobe were not attempted). High potassium may be caused by the presence of chemical alteration of the glass in the presence of seawater, but phosphorus is not commonly found in secondary minerals. The affected glass was depleted in iron, calcium, magnesium, and manganese relative to the fresh glass. Iron and manganese in fresh basalt glass is mostly in the reduced form (Christie et al., 1986), so the low Fe and $\mathrm{Mn}$ in the altered glass may result from the oxidation and release of iron from the glass by microbes. The low $\mathrm{Ca}$ is similar to that observed in the chemical alteration of basalt glass, so the combined effect of chemical and biological processing of basalt glass is probably responsible for the chemistry of the altered areas analyzed by microprobe.

The results reported here provide significant support for the hypothesis that bacteria are somehow involved in the alteration of basaltic glasses to clays.

Note added in proof: Nucleotide sequences indicate that the cloned ribosomal RNA genes are bacterial. At least six different classes of genes have been identified in 61 clones originating from the two rock samples. One of these was identified as a gene from the bacterial genus Thermus, and is almost certainly a contaminant that 
originated in reagents used for PCR. The other genes, which have not been completely studied, belong to a variety of bacterial groups, but are predominately genes from proteobacteria. The largest class of genes in the library has a mole \% guanine + cytosine content close to $50 \%$, which is characteristic of organisms adapted to mesophilic environments. These sequence data suggest that only a traces of DNA were extracted from these rocks, and do not provide proof of the phylogenetic affiliations of the basalt glass microbial community. However, carbon was detected by electron microprobe at the tips of channels, but not elsewhere in the rocks, confirming that the regions of most intense nucleic acid staining have an elemental composition consistent with organic material.

\section{ACKNOWLEDGMENTS}

This work was supported by a grant from the Joint Oceanographic Institutions Program of the National Science Foundation. We thank the Smithsonian Institution for their support to MRF for part of this project. William Melson provided encouragement, Gene Jarosewich and Joe Nelen helped with the electron microprobe, and Tim Gooding prepared the thin sections.

\section{REFERENCES}

Alt, J.C., Laverne, C., and Muehlenbachs, K., 1985. Alteration of the upper oceanic crust: mineralogy and processes in Deep Sea Drilling Project Hole 504B, Leg 83. In Anderson, R.N., Honnorez, J., Becker, K., et al., Init. Repts. DSDP, 83: Washington (U.S. Govt. Printing Office), $217-$ 247.

Christie, D.M., Carmichael, I.S.E., and Langmuir, C.H., 1986. Oxidation states of mid-ocean ridge basalt glasses. Earth Planet. Sci. Lett., 79:397411.

Crovisier, J.L., Honnorez, J., and Eberhart, J.P., 1987. Dissolution of basaltic glass in seawater: mechanism and rate. Geochim. Cosmochim. Acta, 51: 2977-2990.

DeLong, E.F., Wickham, G.S., and Pace, N.R., 1989. Phylogenetic stains: ribosomal RNA-based probes for the identification of single cells. Science, 243:1360-1363.

Duff, R.B., Webley, D.M., and Scott, R.O., 1963. Solubilization of minerals and related materials by 2-ketogluconic acid-producing bacteria. Soil Sci., 95:105-114.

Froelich, P.N., Klinkhammer, G.P., Bender, M.L., Luedtke, N.A., Heath, G.R., Cullen, D., Dauphin, P., Hammond, D., Hartman, B., and Maynard, V., 1979. Early oxidation of organic matter in pelagic sediments of the eastern equatorial Atlantic: suboxic diagenesis. Geochim. Cosmochim. Acta, 43:1075-1090.

Giovannoni, S.J., 1991. The polymerase chain reaction. In Stackebrandt, E., and Goodfellow M. (Eds.), Nucleic Acid Techniques in Bacterial Systematics: New York (Wiley), 177-201.

Giovannoni, S.J., and Cary, S.C., 1993. Probing marine systems with ribosomal RNAs. Oceanography, 6:95-104.

Giovannoni, S.J., DeLong, E., Olsen, G.J., and Pace, N.R., 1988. Phylogenetic group-specific oligodeoxynucleotide probes for in situ microbial identification. J. Bacteriol., 170:720-726.

Hart, R.A., 1970. Chemical exchange between seawater and deep ocean basalts. Earth Planet. Sci. Lett., 9:269-279.

Jarosewich, E., Nelen, J.A., and Norberg, J.A., 1980. Reference samples for electron microprobe analysis. Geostand. Newsl., 4:43-47.

Kapuscinski, J., 1990. Interactions of nucleic acids with fluorescent dyes: spectral properties of condensed complexes. J. Histochem. Cytochem., 38:1323-1329.
Krumbein, W.E., 1983. Microbial Geochemistry: Oxford (Blackwell).

Lane, D.J., 1991. 16S/23S rRNA sequencing. In Stackebrandt, E., and Goodfellow, M. (Eds.), Nucleic Acid Techniques in Bacterial Systematics. New York (Wiley), 115-148.

Laverne, C., 1983. Occurrence of melanite and aegirine-augite in Deep Sea Drilling Project Hole 504B. In Cann, J.R., Langseth, M.G., Honnorez, J., Von Herzen, R.P., White, S.M., et al., Init. Repts. DSDP, 69: Washington (U.S. Govt. Printing Office), 593-605.

Melson, W.G., and Thompson, G., 1973. Glassy abyssal basalts, Atlantic sea floor near St. Paul's Rocks: petrology and composition of secondary clay minerals. Geol. Soc. Am. Bull., 84:703-716.

Miyashiro, A., Shido, F., and Ewing, M., 1969. Diversity and origin of abyssal tholeiite from the Mid-Atlantic ridge, $24^{\circ}$ and $30^{\circ} \mathrm{N}$ latitude. Contrib. Mineral. Petrol., 23:38-52.

Noack, Y., Emmermann, R., and Hubberten, H.-W., 1983. Alteration in Site 501 (Leg 68) and Site 504 (Leg 69) basalts: preliminary results. In Cann, J.R., Langseth, M.G., Honnorez, J., Von Herzen, R.P., White, S.M., et al., Init. Repts. DSDP, 69: Washington (U.S. Govt. Printing Office), 497508.

Palmer, R.J., and Hirsch, P., 1993. Microbial organic acid production and weathering of silicate minerals under simulated groundwater conditions. 1993 Int. Symp. Subsurface Microbiol. (ISSM-93). (Abstract)]

Setlo, R.B., 1966. Cyclobutane-type pyrimidine dimers in polynucleotides. Science, 153:379-386.

Seyfried, W.E., Jr., and Bischoff, J.L., 1979. Low temperature basalt-alteration by sea water: an experimental study at $70^{\circ} \mathrm{C}$ and $150^{\circ} \mathrm{C}$. Geochim. Cosmochim. Acta, 43:1937-1948.

Shipboard Scientific Party, 1993. Site 896. In Alt, J.C., Kinoshita, H., Stokking, L.B., et al., Proc. ODP. Init. Repts., 148: College Station, TX (Ocean Drilling Program), 123-192.

Silverman, M.P., 1979. Biological and organic decomposition of silicates. In Trudinger, P.A., and Swaine, D.J. (Eds.), Biogeochemical Cycling of Mineral-Forming Elements. Stud. Environ. Sci., 3: Amsterdam (Elsevier), 445-467.

Stahl, D.A., and Amman, R.A., 1991. Development and application of nucleic acid probes. In Stackebrandt, E., and Goodfellow, M. (Eds.), Nucleic Acid Techniques in Bacterial Systematics: New York (Wiley), 205-248.

Stahl, D.A., Flesher, B., Mansfield, H.W., and Montgomery, L., 1988. Use of phylogenetically-based hybridization probes for studies of ruminant microbial ecology. Appl. Environ. Microbiol., 54:1079-1084.

Staudigel, H., and Hart, S.R., 1983. Alteration of basaltic glass: mechanisms and significance of the oceanic crust-seawater budget. Geochim. Cosmochim. Acta, 47:337-350.

Thorseth, I.H., Furnes, H., and Heldal, M., 1992. The importance of microbiological activity in the alteration of natural basaltic glass. Geochim. Cosmochim. Acta, 56:845-850.

Thorseth, I.H., Furnes, H., and Tumyr, O., 1991. A textural and chemical study of Icelandic palagonite of varied composition and its bearing on the mechanism of the glass-palagonite transformation. Geochim. Cosmochim. Acta, 55:731-749.

Ward, D.M., Bateson, M.M., Weller, R., and Ruff-Roberts, A.L., 1992. Ribosomal RNA analysis of microorganisms as they occur in nature. Adv. Microb. Ecol., 12:219-286.

Webley, D.M., Henderson, E.K., and Taylor, I.F., 1963. The microbiology of rocks and weathered stones. J. Soil Sci., 14:102-112.

Date of initial receipt: 29 August 1994

Date of acceptance: 27 February 1995

Ms 148SR-151 


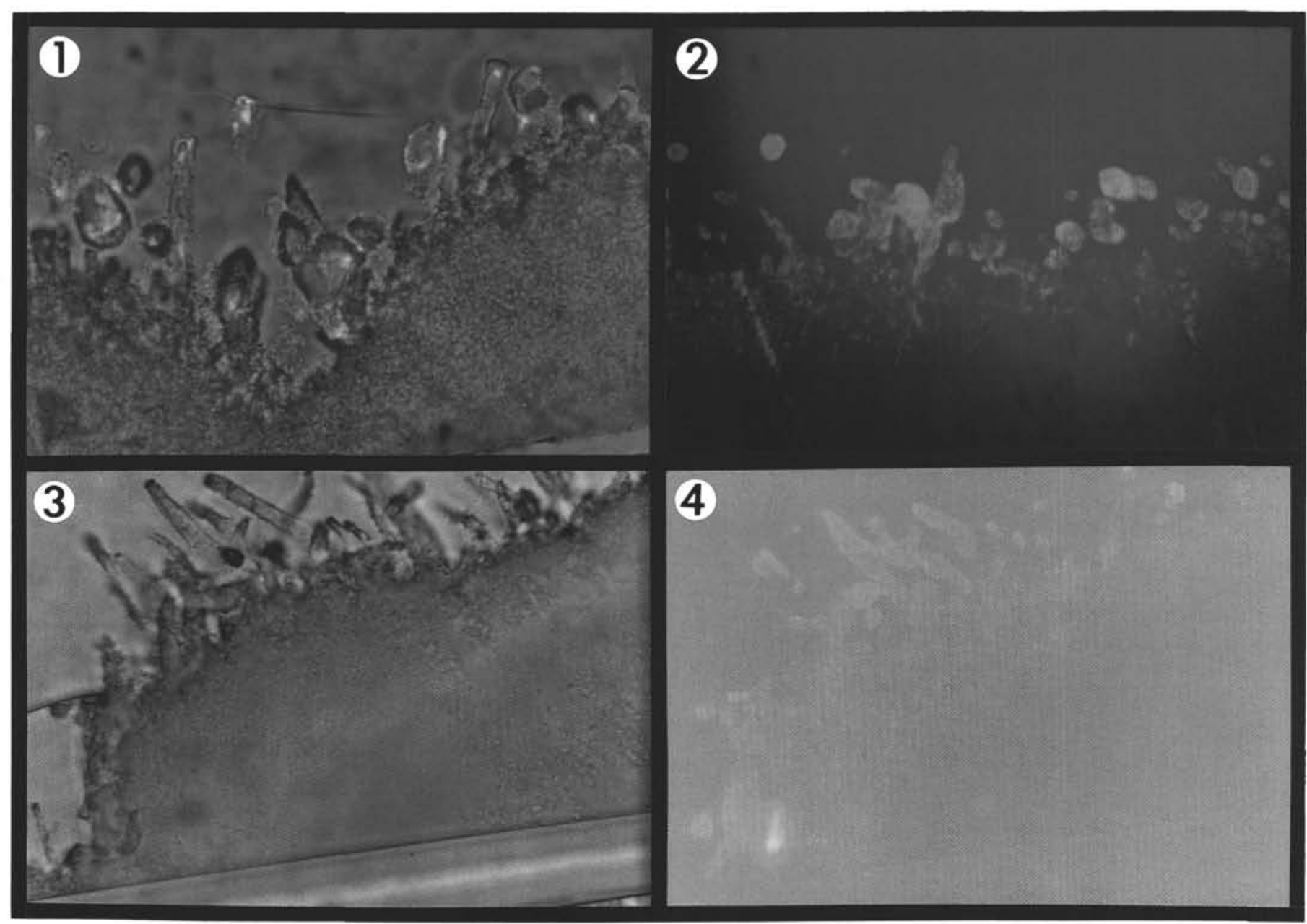

Plate 1. 1. Thin section from Sample 148-896A-7R-1, 52-55 cm (Piece 10) (284 mbsf) viewed under a combination of plain polarized light and epiillumination for Hoescht dye. The long dimension of the photograph is $0.6 \mathrm{~mm}$. The top of the photograph is clear glass with brown microlites. The bottom of the photograph is clay surrounding a crack. A dark brown irregular interface separates the clay and the glass. Hoechst 3342 becomes fluorescent (blue, emission maximum 460 $\mathrm{nm}$ ) upon binding to adenosine/thymidine-rich regions in the minor-groove of DNA. 2. Thin section from Sample 70-5048B-48R-2 viewed by epifluorescence microscopy. The section was stained with PO-PRO-3, a cyanin dye with high affinity for DNA. 3. Thin section from Sample 70-504B-48R, 120-124 cm, viewed by transmitted light. 4 . The thin section shown in Figure 3 stained with the green fluorescent dye Sytoll, which binds to DNA and RNA. The long axis of each image above is $250 \mu \mathrm{m}$. 